\title{
Social and Environmental Disclosure and Earning Persistence
}

\author{
Meliyanti Meliyanti*, Nora Sri Hendriyeni \\ Sekolah Tinggi Manajemen PPM \\ Jakarta, Indonesia \\ *meliy.thd@gmail.com
}

\begin{abstract}
Earnings persistence occurs by several factors such as innate factors (company age, company size, competition) and discretionary factors (risk aversion, auditor quality). Other factors that can influence earnings persistence are non-financial aspects such as social and environmental. Companies that execute good social and environmental activities have a tendency to provide higher quality earnings information to attract investors. This study uses simple and multiple linear regression with an interaction term for determining moderating variables. We also do classic assumption tests beforehand such as normality test, heteroscedasticity test, and multicollinearity test. This study uses 3 Models to determine its Hypothesis. We use 210 data from the mining sector in Indonesia, which processed with purposive sampling. Then we obtained 41 sample data. This study uses social and environmental disclosures with the GRI-G4 index (and only concern about social and environmental category), earnings persistence using a proxy earnings quality, sales volatility with sales variation and debt levels with DTA (Debt to Asset Ratio) as moderated variables. Result shows that it can be concluded that in the mining sector in Indonesia, social and environmental disclosures on earnings persistence has a significant effect.
\end{abstract}

Keywords-earning persistence, social and environmental disclosures, corporate social responsibility

\section{INTRODUCTION}

Based on accounting perspective, earning is an important calculation of the company's performance in the current period [1]. The earnings component is considered important to understand the companies' financial quality. Financial statements can be used by external users such as investors, creditors, governments and analysts. In general, investors pay more attention to the earnings component, creditors pay attention to the level of debt, the government pays attention to the company's accrual revenue or expenditure and financial analyst pays attention to all components to assess the company's going concern. External information users generally make an interpretation or process to understand the quality of a profit. Good quality earnings will reflect the company's operating performance in the current year and accurately support the company's value [2]

Earnings quality can be associated with earnings stability and persistence [3]. Earnings persistence is expected earnings in the future and reflected in the current year [4]. Companies with complex financial statement presentations have low earnings persistence. While an easy-understandable financial statements have high earnings persistence potential [5]. In this case, the financial statements can be used as a proxy to predict whether the company is doing earnings persistence which has an effect on earnings quality.

Earnings persistence occurs by several factors such as innate factors (company age, company size, competition) and discretionary factors (risk aversion, auditor quality) [3,6]. According to Francis et al, these factors originate from financial motives such as litigation costs, ownership costs, disclosure fees, transaction costs, information asymmetries and others [6]. In addition, other factors can influence earnings persistence are non-financial aspects such as social and environmental. Companies that execute good social and environmental activities have a tendency to provide higher quality earnings information to attract investors [3].

According to Fanani, there are two viewpoints in measuring earnings persistence [7]. The first view relates to the company's performance which is reflected in the company's profit. Persistent earnings can describe the sustainability of earnings (sustainable earnings) in the future [4,7]. Therefore, earnings persistence is the centre of attention, especially investors, to better understand the relationship between current earnings and permanent profits $[8,9]$.

While the second view, earnings persistence is related to the performance of company stock prices in the capital market $[6,7]$. This relationship is associated with yields received by investors. The stronger the company's yield and profit relationship, the higher the persistence of earnings [7]. This will be related to the company's stock performance in the capital market. If the company has high earnings persistence, the value of its shares will be maintained because investors want a high return or yield. This will certainly attract investors to invest in the company.

On the other side, two of the financial factors are the level of sales volatility and debt levels. Volatility sales illustrate the quality of profits [3] because it has an effect on the level of profits that will cause a lot of changes (noise) [7]. On the other hand, if the company's profits are unable to pay the interest expense (due to debt) and its principal, then it will lead to failure and is believed to be unable to obtain a stable profit [7].

In previous studies explained that the quality of information available on CSR (Corporate Social Responsibility) can improve company performance, especially profitability [10]. Other studies explain that social and environmental policies have a positive relationship with earnings quality [3]. According to Laksmana and Yang, companies that disclose social and environmental information on financial statements, have stable earnings that affect earnings persistence compared 
to other companies [11]. This research is focused on social and environmental disclosure on CSR reports on earnings quality, which used as a proxy for earnings persistence with sales volatility and debt level as moderation variables. The research also focused on sectors that have direct social and environmental effects, evidence from the mining sector in Indonesia. This research was conducted in Indonesia from 2014 to 2018

\section{PRIOR LiteratURE}

\section{A. SED (Social and Environmental Disclosures)}

In Indonesia, policies regarding the implementation of SED have been regulated in Indonesian Law Number 40 of 2007 concerning Limited Liability Companies (PT) with the development of government regulations (PP) in 2012 regarding, precisely in PP 47/2012. Then in line with developments the need for information on the industry, the OJK (Otoritas Jasa Keuangan) issued a policy with SAL POJK Number 51 / POJK.03 in 2017 regarding the implementation of sustainable finance which contains the company's responsibilities in issuing reports on SED. But on the other hand, policies regarding disclosure of social and environmental activities are still uneven. Therefore, there are still many public companies that make voluntary disclosures.

SED activities has 2 approaches. The first approach is through ISO (The International Organization for Standardization). In September 2004, ISO was formed as the parent organization of international standardization, taking the initiative to invite parties and form a team that gave birth to guidelines and standardization for social responsibility. Until the final formation of the SED guidelines, ISO issued ISO 26000: Guidance Standard on Social Responsibility. In this guideline, the guideline standard is voluntary regarding the social responsibility of an institution that covers all sectors of public and private bodies, both in developing and developed countries.

Whereas the second approach is to use the GRI (Global Reporting Initiative) index. GRI is an independent organization in the practice of sustainable information disclosure, supporting companies to protect the environment and improve the welfare of society and improve governance, reputation and trust. Currently the last guideline issued by GRI is in May 2013 regarding Sustainability Reporting Guideliness-G4 with 91 disclosure points.

The unequal application of CSR in Indonesia results in different disclosures for the implementation of CSR in various industries. Even though ISO 26000 is used as a reference for making SR guidelines voluntarily, GRI G-4 is one of the international guidelines that can be used as a permanent guideline in Indonesia by using generally accepted sustainability reports.

\section{B. Earning Persistence}

Earnings persistence is an indicator of earnings quality used by users of financial statements to evaluate earnings sustainability as a component of decision making [2]. Earnings persistence can also describe information about future profits (future earnings) and potential management behaviour [5]. Earnings persistence can be used to predict future returns. If the current year's earnings are able to project future earnings accurately [9], then the company's profits can be said to be persistent. In general persistent earnings are earnings that tend to be stable and not fluctuating. In the financial literature, Mahjoub and Khamoussi states that the current year's earnings component can be said to be persistent if it is stable in the future [3].

In its measurement, earnings persistence can be used as a proxy for earnings quality. According to Francis et al, earnings persistence as earnings quality is based on more stable earnings with high earnings [12]. Dechow and Schrand, explained that there are three things that reflect earnings quality, namely earnings that reflect the company's performance in the current year, showing future performance and a collection of information that is useful for assessing a company's value [2]. Earnings persistence as earnings quality is based on a decision perspective, specifically regarding the valuation of equity or capital [13]. On the other hand, the quality of a profit varies in the company [2]. There are four things that underlie earnings quality, namely, earnings component data from time to time, qualitative characteristics selected in the FASB Conceptual Framework (Financial Accounting Standards Board), relationships with components of income, cash flow and accruals and company implementation decisions [13]. Moreover, Schipper and Vincent also explained in the FASB Conceptual Framework, the quality of earnings is based on the perspective of the benefits of decision making based on the information provided [13]. This can be seen from the qualitative characteristics (basic qualitative and level of quality) as well as financial and non-financial information.

\section{Sales Volatility}

In Mahjoub and Khamoussi, variations on changes in sales are proxied as sales volatility [3]. Sales volatility can also be explained as a change in sales that cannot be predicted. Sales volatility can also indicate a fluctuating company operating environment and the possibilities of companies using estimates and estimates [14]. The company can also make mistakes in the appropriate estimates and the low quality of the company's accruals. Thus, the higher the level of sales volatility is the lower the accrual quality of the company. In addition, the argument that a high level of corporate sales volatility has a higher risk [15].

\section{Debt Level}

In general, the level of debt can be used as one of the measurement variables in earnings management studies [1] Indirectly, companies that have high levels of debt can affect the level of return on company profits. Therefore, the level of debt can affect the level of earnings quality of a company [16]. On the other hand, the cost of debt is also a determinant factor in the company's sustainability reporting strategy [17]. This can indicate that the level of corporate profits can be influenced by the level of debt. 


\section{THEORETICAL FRAMEWORKS AND HYPOTHESIS DEVELOPMENT}

First the existence of stakeholder theory, companies are encouraged to participate in activities that are beneficial (to the social or the community) and take advantage of these activities as a strategic tool to maximize value and increase profits [3]. CSR disclosure can affect stakeholder perceptions [18]. By disclosing CSR in financial statements, companies can provide information relating to social and environmental issues. This is also because CSR reports must be disclosed transparently and in accountability, so that CSR disclosures can be considered relevant to users of financial statements [3].

Signal theory also provides a unique, practical and empirically tested perspective on social and environmental problems in the imperfection of information [19]. Gray argues that companies that disclose their social and environmental activities aim to give signals about the quality of management, risk management and reputation of management [20]. Furthermore, Gray also argues that the quality of financial statements is not very important, but the existence of these financial statements is very important to give a signal to the capital market or parties that favour the company [20]. One of them is by disclosure of non-financial activities such as social and environmental.

Disclosure of good social and environmental activities, helps companies to get a good reputation or image in business [3]. Investors who catch a signal of this information will be interested in investing capital, consumer loyalty will increase and the government will feel helped by social and environmental activities undertaken by the company. Companies that focus on disclosure of social and environmental activities on financial statements, give signals to users that the company is a 'good company' [21]. Therefore, any information released by the company whether related to finance or not, is important as an indication or signal to parties who have an interest.

In SED activities, companies tend to give signals to users (third parties) that the company has a good reputation, is able to see risks well and has quality management [20]. In economic development, people no longer only see one particular component (such as finance) as a component of company decisions. In addition, the company is concerned with social and social activities to improve public image. Tanudjaja explained that companies no longer carry out SED activities based on legal responsibilities but also for humanitarian responsibilities especially for the going concern of the company itself [22]. Therefore, the disclosure of TJSL can influence the perception of related stakeholders [18].

\section{A. Hypothesis 1}

That way, the existence of reports in non-financial disclosures such as social and environmental activities, is considered important in maintaining the level of stability of the company, especially at the level of corporate profits. This is because stable profits can describe quality information and future benefits and management behaviour [5]. Much of the literature looking at this condition is then examined its effect on firm value [23,24], with firm performance [10], and earnings management [18,21]. Bidhari et al states that by increasing the CSR information, company performance will improve specifically the level of profitability [10]. The same thing was also expressed by Retno $\mathrm{M}$ and Priantinah who explained that the SED had a positive effect on the value of the company and the level of profitability [24]. Other research explains the policy on the disclosure of social and environmental activities can affect earnings quality in the country with the disclosure of TJSL (such as earnings management, income smoothing and others) [3]. The researcher realizes that with the SED activities, the company has a level of profit that tends to be more stable than companies that are less committed in disclosing CSR. Researchers argue similar to previous studies, that companies with higher disclosure rates have more stable growth and profit rates. Based on the theory and research that has been done, the formulation of the hypothesis is as follows:

H1: SED activities has a negative effect on earnings persistence.

\section{B. Hypothesis 2}

As one of the company's efforts to improve the environment and social inequalities that occur, the company carries out social and environmental activities and then discloses it in the CSR report [24]. With the commitment in the SED, the company also seeks to build an image to the community. This will certainly bring public confidence in buying products from the company. The company will then get a sale because it is considered a trustworthy company. Companies that disclose information well and can be trusted will have a stable advantage [3].

The level of variation in sales from year to year will also illustrate the quality of company profits so that this level of variation is also called sales volatility [3]. Sales volatility can be indicated as one of the innate factors in measuring the earnings quality of a company $[6,12,14]$. Sales volatility can be used as a proxy of the level of sales variation [3]. According to Dechow and Dichev, variation in sales is negatively related to earnings persistence [14]. The greater the variation of sales, the lower the level of earnings persistence. This is because the company provides incorrect information so that it is not able to maintain earnings quality or earnings are not constant.

Other literature states that companies with high levels of sales tend to have constant earnings [25]. Fanani argues that if the level of sales volatility is high, it will affect earnings persistence so that earnings persistence will be low [7]. This means that if there are large changes in sales, it can affect the level of stability of the company's profit. Therefore, with the SED activities that can affect the level of sales variation so that the level of company earnings persistence will be affected. Based on the theory and research that has been done before, the formulation of the hypothesis is as follows:

H2: SED activities has a positive effect on earnings persistence using sales volatility as a moderating variable. 


\section{Hypothesis 3}

Financial statements have an important role in addition to being a form of corporate responsibility in providing financial information, but also as an effort for companies to obtain additional funds. The company's annual report which now contains financial and non-financial information can be used as a report to obtain additional funding from external parties. The funds obtained can be in the form of share capital or other sources of funds such as debt. Companies with good growth need adequate sources of funds. Therefore, debt can be used as one of the financial components of the company to obtain additional sources of funds.

Debt levels are generally used as control variables in earnings management measurement studies [1]. High levels of debt can affect company expenses in paying interest expenses. This will affect the level of corporate profits. High levels of debt are associated with low quality of earnings [16]. Gu et al, Tumirin and Saputra in Fanani explain that a high level of debt will increase the company's efforts to increase earnings persistence [7]. This is done by the company to maintain good performance so that information conveyed through financial statements can be assessed both by stakeholders. On the other hand, the estimated profit is too high to cover the company's ability to pay off the actual debt so that it can provide misleading information to creditors [7]. Indirectly, the level of debt affects the return on corporate profits. Economically, the cost of debt (proprietary costs) is a significant determinant in the strategy of reporting on social activities and corporate environment [17]. In other literature explains that the level of debt can affect companies on earnings management [26]. This is similar to the research revealed by Mahjoub and Khamoussi which states that the level of debt can affect the level of earnings quality [3]. Based on the theory and research that has been done before, the formulation of the hypothesis is as follows:

H3: SED activities has a negative effect on earnings persistence using the level of debt as a moderating variable.

\section{EMPIRICAL VALIDATION AND VARIABLE DESCRIPTION}

We use 210 data from the mining sector in Indonesia, which processed with purposive sampling. Then we obtained 41 sample data. This study uses social and environmental disclosures with the GRI-G4 index (and only concern about social and environmental category), earnings persistence using a proxy earnings quality (this proxy is a negative coefficient value from the annual earnings regression model (AR1 model) with the following calculation [3,7,12], sales volatility with sales variation and debt levels with DTA (Debt to Asset Ratio). This study also uses control variables such as company size variables (log to total asset) and audit quality (dummy variables of big4 and non-big4 companies).

\section{A. SED (Social and Environmental Disclosures) - known as Disclosures of CSR (Corporate Social Responsibility)}

Disclosure of social and environmental activities can be found in the annual report or sustainability report (SR / CSR Report) precisely in the Social and Environmental Responsibility (SR) section of the company concerned. In this study, the measurement of each item disclosed in the report is given a value of 1 and vice versa if there is no disclosure given a value of 0 . This disclosure is assessed according to GRI-G4 guidelines. The level of disclosure of social and environmental activities will be assessed by comparing the number of disclosures made by the company with the amount required in GRI-G4. The research disclosure items only focus on social and environmental categories as well as specific categories for the mining industry. The number of disclosures is 87 items.

\section{B. Earning Persistence}

In this study, earnings persistence uses a proxy for the calculation of earnings quality, namely by using EPS (Earning per Share). This proxy is a negative coefficient value from the annual earnings regression model (AR1 model) $[3,7,12]$. The higher the persistence value of earnings on this measurement, it shows the less persistent earnings. Therefore, it can be said that the lower the measurement value of earnings persistence, the more persistent it shows.

\section{Moderated Variables}

This study uses 2 moderating variables such as Sales Volatility and Debt Levels. Below are the measurements of each moderated variable:

1) Sales volatility: In this study, the measurement of sales volatility uses a proxy for sales variations. Sales volatility is used as one of the moderation variables.

2) Debt levels: In relation to earnings quality, rising debt levels indicate decreasing earnings quality [27]. The level of debt can be measured using financial ratios such as the DTA ratio (Debt to total Asset ratio). This ratio is also referred to as one way to calculate the solvency ratio or leverage ratio. Therefore, the level of debt is used as one of the moderation variables in this study.

\section{Control Variables}

This study uses 2 control variables such as Company Size and Audit Quality. Below are the measurements of each moderated variable:

1) Company size: In this study, one of the control variables used is firm size.

2) Audit quality: Audit quality is measured based on the use of a Public Accounting Firm (KAP) as in table 1. If the company uses KAP Big4 (KPMG, EY, PWC and Deloitte) is rated 1 and vice versa, if the company uses KAP non-Big4 rated 0 .

TABLE I. VARIABLES MEASUREMENTS

\begin{tabular}{|c|c|c|}
\hline Variables & Measurement & \\
\hline $\begin{array}{ll}\text { Social } & \text { and } \\
\text { Environtment } & \\
\text { Disclosure } & \end{array}$ & $\begin{array}{l}\text { CSR Report vs GRI Index (G4) = } \\
\text { item disclosures / } 87\end{array}$ & \\
\hline \multirow[t]{3}{*}{ Earning Persistence } & EPS = Earning per share & \multirow{3}{*}{$\begin{array}{l}\text { Negative slope from } \\
\text { regression model of } \\
\text { Francis et al [6] }\end{array}$} \\
\hline & $\mathrm{EPS}_{\mathrm{jt}}=\beta_{0}+\beta_{1} \mathrm{EPS}_{\mathrm{jt}-1}+\varepsilon_{\mathrm{jt}}$ & \\
\hline & $\begin{array}{l}\text { For each firm i and year t, EPS is net } \\
\text { income before extraordinary items of } \\
\text { outstanding shares. Larger (smaller) } \\
\text { values of PERST correspond to less } \\
\text { (more) persistent earnings. }\end{array}$ & \\
\hline
\end{tabular}


Table 1. Cont.

\begin{tabular}{|l|l|l|}
\hline \multicolumn{1}{|c|}{ Variables } & \multicolumn{1}{|c|}{ Measurement } & \\
\hline Moderated Variable & & \\
\hline Debt Level & Debt/total asset & \\
\hline Sale Volatility & {$[\{$ sales $\mathrm{t}$ - sales t-1\}/ sales t-1] } & Sales variation \\
\hline Control Variable & & \\
\hline Audit Quality & Big4 and non Big4 & $\begin{array}{l}\text { Dummy: coded 1 in } \\
\text { case of company } \\
\text { audited by big 4 } \\
\text { auditor and 0 } \\
\text { otherwise }\end{array}$ \\
\hline Firm size & & $\begin{array}{l}\text { Natural logarithm of } \\
\text { total assets }\end{array}$ \\
\hline
\end{tabular}

\section{RESUlTS AND Discussion}

\section{A. Model 1}

TABLE II. REGRESSION ANALYSIS: RELATION BETWEEN SED AND PERST

\begin{tabular}{|l|l|l|l|l|}
\hline \multicolumn{1}{|c|}{ Variable } & \multicolumn{1}{c|}{ Coeff. } & \multicolumn{1}{c|}{ Std err. } & \multicolumn{1}{c|}{$\mathbf{P}$} & \multicolumn{1}{c|}{$\mathbf{| t |}$} \\
\hline Sed & -.3947378 & .167467 & -2.36 & 0.024 \\
\hline FirmS & .1102033 & .1389925 & 0.79 & 0.433 \\
\hline AuditQlty & 15.2962 & 5.981885 & 2.56 & 0.015 \\
\hline cons & 8.473478 & 7.673453 & 1.10 & 0.277 \\
\hline Obs. 41 , R-Squared $=0.2131(21.31 \%)$, Prob. $>\mathrm{F}=0.0165$ \\
\hline
\end{tabular}

Based on the regression results in table 2 , the $F$ test value is 0.0165 . So it can be concluded that the sed (social and environmental disclosures) variable simultaneously has a significant influence on earnings persistence (PERST). It can be seen that the RSquared value of 0.2131 means that all independent variables can explain the PERST variable of $21.31 \%$. The minus sign on the regression coefficient $\left(\beta_{1} X_{1}=\right.$ 0.3947378 sed) indicates that the relationship between disclosure of social and environmental activity with earnings persistence is negative. In this case, the lower PERST value indicates more persistence. In column $\mathrm{P}>(\mathrm{t})$, it is explained that the level of the sed variable is 0.024 , which is less than 0.05 . Therefore, it can be concluded that the function model PERST $=8,473478-0,3947378$ sed + e.

\section{B. Model 2}

TABLE III. REGRESSION ANALYSIS: RELATION BETWEEN SED AND PERST WITH SED VOLSALES (MODEL 2)

\begin{tabular}{|c|c|c|c|c|}
\hline Variable & Coeff. & Std err. & $\mathbf{t}$ & $P>|t|$ \\
\hline Sed & -0.1541603 & 0.3890246 & \begin{tabular}{|l|}
-0.40 \\
\end{tabular} & 0.694 \\
\hline VolSales & 0.0155363 & 0.2601175 & 0.06 & 0.953 \\
\hline sed*VolSales & -0.011458 & 0.0166176 & -0.69 & 0.495 \\
\hline FirmS & 0.1408739 & 0.1460414 & 0.96 & 0.341 \\
\hline AuditQlty & 15.31934 & 5.872517 & 2.61 & 0.013 \\
\hline _cons & 7.53316 & 9.174405 & 0.82 & 0.417 \\
\hline
\end{tabular}

Based on the results of the regression in table 3 , the value of the F test is 0.0165 . So it can be concluded that the sed variable simultaneously has a significant influence on earnings persistence (PERST) in the presence of volatility sales as moderating variable. It can be seen that the R-Squared value of 0.2452 means that all independent variables can explain the PERST variable of $24.52 \%$. Then the remaining $75.48 \%$ is influenced by other variables outside the regression model. In column $\mathrm{P}>(\mathrm{t})$ it is explained that the level of sed variable is 0.694 and the VolSales variable is 0.953 and the interaction variable sed * VolSales is 0.495 . This means that partially the above variables do not have a significant effect on the PERST variable.

\section{Model 3}

TABLE IV. REGRESSION ANALYSIS: RELATION BETWEEN SED AND PERST WITH SED DEBT LVL (MODEL 3)

\begin{tabular}{|c|c|c|c|c|}
\hline Variable & Coeff. & Std err. & t & $P>|t|$ \\
\hline sed & -0.6241492 & 0.5627787 & -1.11 & 0.275 \\
\hline DebtLvl & -0.2069483 & 0.4349082 & -0.48 & 0.637 \\
\hline sed*DebtLvl & 0.0082173 & 0.0229721 & 0.36 & 0.723 \\
\hline FirmS & 0.1495283 & 0.1717303 & 0.87 & 0.390 \\
\hline AuditQlty & 14.73914 & 6.821516 & 2.16 & 0.038 \\
\hline _cons & 13.77763 & 13.2412 & 1.04 & 0.305 \\
\hline \multicolumn{4}{|c|}{$\begin{array}{l}\text { Obs. 41, R-Squared }=0.2196(21.96 \%), \text { Prob. }>\mathrm{F}= \\
0.0552\end{array}$} & \\
\hline
\end{tabular}

It can be seen in table 4 that the R-Squared value of 0.2196 means that all independent variables can explain the PERST variable of $21.96 \%$. Then the remaining $78.04 \%$ is influenced by other variables outside the regression model. Based on the regression results, the $F$ test value is 0.0552 . So it can be concluded that simultaneously the sed variable does not have a significant influence on earnings persistence (PERST). In column $\mathrm{P}>(\mathrm{t})$ it is explained that the level of sed variable is 0.275 and the DebtLvl variable is 0.637 and sed * DebtLvl is 0.723 . This means that partially the independent variables described in model 3 do not significantly influence the PERST.

\section{CONCLUSION}

This study aims to determine the effect of disclosure of social and environmental activities on earnings persistence in the mining sector in Indonesia. It is also to find out the effect of disclosure of social and environmental activities on earnings persistence with interactions shown in moderating variables such as sales volatility and debt levels. Based on the results of research and discussion and analysis of research, it can be concluded that in the mining sector in Indonesia, social and environmental disclosures on earnings persistence has a significant effect. On the other hand, moderating variables such as sales volatility and debt levels, apparently do not have a significant effect on the relationship between disclosure of social and environmental activities on earnings persistence. This can be due to the level of variation in sales and the level of debt is different from the implications of the results of previous studies. In addition, this study uses a purposive sampling method in sampling. 
On the other hand, this research was first carried out in the mining sector in Indonesia. There are a number of suggestions given so that it can be utilized in subsequent studies, which can use other moderation variables such as (1) the level of cash flow volatility, because several studies have shown the consistency of research results in their effects on earnings persistence. Other research explains that if there is a high variation in cash flow, it will affect the company's earnings. Which (2) with Book-tax-difference, several studies explain that the difference in the calculation of commercial tax on corporate profits with fiscal profit calculations related to information on corporate profits

\section{REFERENCES}

[1] R. Oei, A. Ramsay, and P. Mather, "Earnings persistence, accruals and managerial share ownership," Accounting and Finance, vol. 48, pp. 475502, 2008

[2] P.S. Dechow, Earnings Quality. The Research Foundation of CFA Institute, 2004.

[3] L.B. Mahjoub and H. Khamoussi, Environmental and Social Policy and Earning Persistence. Business Strategy and the Environment, 2012.

[4] S.H. Penman, "On comparing cash flow and accrual accounting models for use in equity valuation: A response to Lundholm and O'Keefe (CAR, Summer 2001)," Contemporary Accounting Research, vol. 18, no. 4, pp. 681-692, 2001.

[5] F. Li, "Annual report readability, current earnings, and earnings persistence," Journal of Accounting and Economics, vol. 45, pp. 221$247,2008$.

[6] J. Francis, P.M. Olsson, and K. Schipper, "Earnings Quality," Foundations and Trends in Acounting, vol. 1, no. 4, pp. 259-340, 2008.

[7] Z. Fanani, "Analisis Faktor-Faktor yang Mempengaruhi Persistens Laba," Jurnal Akuntansi Dan Keuangan Indonesia, vol. 7, no. 1, pp. 109-123, 2010

[8] B. Blaylock, T. Shevlin, and R.J. Wilson, "Tax Avoidance, Large Positive Temporary Book-Tax Differences, and Earnings Persistence," American Accounting Association, vol. 87, no. 1, pp. 91-120, 2012.

[9] R. Frankel and L. Litov, "Earnings persistence," Journal of Accounting and Economics, vol. 47, no. 1-2, pp. 182-190, 2009.

[10] S.C. Bidhari, U. Salim, and S. Aisjah, "Effect of Corporate Social Responsibility Information Disclosure on Financial Performance and Firm Value in Banking Industry Listed at Indonesia Stock Exchange," European Journal of Business and Management, vol. 5, no. 18, pp. 39 47, 2013.

[11] I. Laksmana and Y.W. Yang, "Corporate citizenship and earnings attributes," Advances in Accounting, vol. 25, no. 1, pp. 40-48, 2009.

[12] J. Francis, R. LaFond, P.M. Olsson, and K. Schipper, "Costs of Equity and Earnings Attributes," The Accounting Review, vol. 79, no. 4, pp. 967-1010, 2004
[13] K. Schipper and L. Vincent, "Earning Quality," Accounting Horizons," pp. 97-110, 2003

[14] P.M. Dechow and I.D. Dichev, "The Quality of Accruals and Earnings: The Role of Accrual Estimation Errors," The Accounting Review, vol 77, pp. 35-59, 2002.

[15] K.R. Tuli, S.G. Bharadwaj, and A.K. Kohli, "Ties That Bind: The Impact of Multiple Types of Ties with a Customer on Sales Growth and Sales Volatility," Journal of Marketing Research, vol. XLVII, pp. 36-50, 2010

[16] P.M. Dechow, W. Ge, and C. Schrand, "Understanding earnings quality: A review of the proxies, their determinants and their consequences,' Journal of Accounting and Economics, vol. 50, no. 2-3, pp. 344-401, 2010 .

[17] D. Cormier and M. Magnan, "Environmental reporting management: A continenal European perspective," Journal of Accounting and Public Policy, vol. 22, no. 1, pp. 43-62, 2003

[18] E. Yip, C. Staden, and S. Cahan, "Corporate Social Responsibility Reporting and Earning Management: The Role of Political Costs,' Australasian Accounting Business and Finance Journal, vol. 5, no. 3, pp. 17-34, 2011.

[19] B.L. Connelly, S. Trevis Certo, R. Duane Ireland, and C.R. Reutzel, "Signaling Theory: A Review and Assessment," Journal of Management, vol. 37, no. 1, pp. 39-67, 2011.

[20] R. Gray, "Taking a Long View on What We Now Know About Social and Environmental Accountability and Reporting," Issues in Social and Environmental Accounting, vol. 1, no. 2, pp. 169-198, 2007.

[21] B. Scholtens and F.C. Kang, "Corporate social responsibility and earnings management: Evidence from Asian economies," Corporate Social Responsibility and Environmental Management, vol. 20, no. 2, pp. 95-112, 2013

[22] B.B. Tanudjaja, "Perkembangan Corporate Social Responsibility D Indonesia," Nirmana, vol. 8, no. 2, pp. 98-98, 2006.

[23] R.M. Ariono, H. Maslichah, and A. Afifudin, Pengaruh Corporate Social Responsibility terhadap Nilai Perusahaan dengan Profitabilitas sebagai Variabel Moderating. Fakultas Ekonomi Universitas Islam Malang, 2016

[24] M.R.D. Retno and D. Priantinah, "Pengaruh Good Corporate Governance dan Pengungkapan Corporate Social Responsibility Terhadap Nilai Perusahaan (Studi Empiris Pada Perusahaan)," Jurna Nominal, vol. I, no. 1, pp. 84-103, 2012.

[25] B. Lev, "Some economic determinants of time-series properties of earnings," Journal of Accounting and Economics, vol. 5, no. C, pp. 3148, 1983.

[26] H.B. Othman and D. Zeghal, "A study of earnings-management motives in the Anglo-American and Euro-Continental accounting models: The Canadian and French cases, International Journal of Accounting, vol. 41, no. 4, pp. 406-435, 2006.

[27] A. Ghosh and D. Moon, "Corporate debt financing and earnings quality," Journal of Business Finance and Accounting, vol. 37, no. 5-6, pp. 538-559, 2010. 